\title{
VARIATION IN SIZE-DEPENDENT FITNESS COMPONENTS IN A TERRESTRIAL ORCHID, DACTYLORHIZA MAJALIS (RCHB.) HUNT ET SUMMERH., IN RELATION TO ENVIRONMENTAL FACTORS
}

\author{
LUCYNA MRÓZ, PIOTR KosiBA \\ Department of Ecology, \\ Biogeochemistry and Environmental Protection, Wrocław University \\ Kanonia 6/8, 50-328 Wrocław, Poland \\ e-mail: mrozl@biol.uni.wroc.pl
}

(Received: April 20, 2010. Accepted: September 29, 2010)

\begin{abstract}
We investigated the flowering probability and flower production in relation to plant size in a terrestrial orchid, Dactylorhiza majalis at 10 meadow sites in central and southwestern Poland. These sites differed in altitude (low, high) and management (presence or absence of mowing). At all sites, concentrations of nutrients in the soil were also measured. The probability of flowering increased significantly with the size of the plant in all populations, indicating that individuals do not flower until they reach a threshold size. Populations at high altitudes and the unmown sites had significantly lower threshold sizes for reproduction and showed sharp increase in flowering probability with plant size, compared to other populations. The threshold sizes for reproduction tended to decrease at sites rich in $\mathrm{N}$ and $\mathrm{Mg}$ and poor in $\mathrm{P}$ and $\mathrm{S}$. Flower production was also size-dependent in all populations. Considerable between-site differences were found in the slope and the intercept of the regression between plant size and flower production. Flower production at some sites, at high altitudes, increased more steeply with plant size than at other sites. However, no pattern in size-dependent flower production was found relative to the measured environmental variables. Most of the size-dependent components of flowering probability were related to each other but not with the size-dependent flower production.
\end{abstract}

KEY WORDS: terrestrial European orchid, total leaf area, plant size, flowering probability, flower production, threshold size for reproduction

\section{INTRODUCTION}

Fitness may be defined as the ability of an individual to produce offspring that reach reproductive maturity (Begon et al. 2008). Direct measurements of the fitness of individual plants are impossible (Lienert 2004). Components of fitness used to estimate fitness of individuals are, for example, the flowering probability, number of flowers and seeds produced (Willems and Ellers 1996; Méndez and Karlsson 2004; Linert 2004; Weiner et al. 2009). Generally, number of flowers and number of seeds are correlated with the size of the producing plants (Willems and Ellers 1996; Ehlers and Olesen 2004; Kuss et al. 2008; Weiner et al. 2009). In many semelparous species, the probability of flowering is also size-dependent, so that plants must exceed a critical threshold size before flowering (Wesselingh et al. 1993, 1997; Kuss et al. 2008; Kagaya et al. 2009). A threshold size that cues the onset of reproduction has also been found in some iteroparous species (Karlsson and Jacobson 2001; Pino et al. 2002; Méndez and Karlsson 2004), although some species do not show evidence of a signifi- cant minimum size requirement for reproduction (Rees and Crawley 1989). There are also a few species in which flowering probability depends on both size and age (Metcalf et al. 2003). Threshold sizes for reproduction are frequently variable across plant populations, and in adverse environments they may tend to be lower than those in favourable environments (Wesselingh et al. 1997; Méndez and Karlsson 2004). Bonser and Aarssen (2009) state that delaying the onset of reproduction in unfavourable environments could result in total reproductive failure if the environmental stress prevents a plant from achieving the optimal size for the initiation of reproduction. Variation in size-dependent reproduction has important implications for plant adaptation and fitness across environments (Bonser and Aarssen 2009). An organism may have greater evolutionary fitness over the long term if it postpones reproduction or limits the allocation of energy to reproduction in the current year (Rockwood 2006).

For many terrestrial orchids, plant size is an important trait that determines the reproductive output. In some species, increased plant size leads to higher flowering pro- 
bability and/or greater production of flower or greater allocation of resources to flowering (Calvo 1990; Willems and Ellers 1996; Willems and Melser 1998; Primack and Stacy 1998; Wells et al. 1998; Brzosko 2002, 2003; Gregg 2004; Hrivnák et al. 2006). According to Wells et al. (1998), Willems and Dorland (2000) and Kull (2002), in some terrestrial orchids, achievement of a threshold size for reproduction is required for flowering. However, flowering does not only depend on the condition of a plant (expressed in size), but is also determined by external factors such as habitat, community structure and climate (Willems and Ellers 1996; Dijk and Grootjans 1998; Wells et al. 1998; Brzosko 2002, 2003; Janečková et al. 2006). Since there is general lack of information about the importance of environmental factors in size-dependent reproduction in terrestrial orchids, the objective of this study is to explore the effect of soil, topography and site management variables on the variation in size-dependent flowering probability and flower production of terrestrial orchid, Dactylorhiza majalis.

D. majalis is the most common meadow orchid in Poland. It occurs from lowlands to mountains. It is not considered endangered nationwide, but the rapid decline of its natural sites or decrease of number of individuals in sites has caused it to be considered a near threatened species in southwestern Poland (Mirek et al. 2003; Kącki et al. 2003). Conservation of threatened species requires knowledge of the effects of the environment on components of life-history strategy and hence fitness of a given species. This knowledge may be helpful for predicting population changes in the future. In this study, we tested whether: (1) the relationship between plant size and flowering probability and flower production change in different environments, (2) size-dependent flowering probability, threshold size for flowering, percentage reproductives and sizedependent flower production are correlated with each other and (3) variation in these size-dependent fitness components is significantly correlated with specific environmental variables.

\section{MATERIAL AND METHODS}

\section{Species and study sites}

The western marsh orchid [Dactylorhiza majalis (Reichenb.), Hunt et Summerhayes] is a long-lived, iteroparous, tuberous perennial growing mainly in Central Europe. It occurs in wet to damp meadows, marshes and fens, mostly on slightly acidic, neutral or alkaline soils. It tolerates light shade, but it does not grow in deep shade. The traditional management of meadows (regular yearly mowing) appears to have created particularly favourable conditions for its survival (Janečková et al. 2006). Dormancy seldom occurs in prosperous populations of this species (Kindlmann and Balounová 1999). Leaves of $D$. majalis emerge above ground usually in April and last until July. Flowering takes place from May to June. The flowers are born in one spike and open sequentially. Usually, it

TABLE 1. Location, coordinates, altitude, habitat type, area extent of population and population size for the 10 sites of Dactylorhiza majalis in central (sites 1-3) and southwestern (sites 4-10) Poland.

\begin{tabular}{|c|c|c|c|c|c|c|}
\hline Site & Location & Coordinates & $\begin{array}{l}\text { Altitude } \\
\text { (m a.s.1) }\end{array}$ & Habitat type & $\begin{array}{c}\text { Area } \\
\text { extent } \\
\left(\mathrm{m}^{2}\right)\end{array}$ & $\begin{array}{l}\text { Population } \\
\text { size* }\end{array}$ \\
\hline 1 & Południowo-Mazowieckie Hills & $\begin{array}{l}51^{\circ} 31^{\prime} 24^{\prime \prime} \mathrm{N} \\
20^{\circ} 14^{\prime} 05^{\prime \prime} \mathrm{E}\end{array}$ & 140 & $\begin{array}{l}\text { Mown wet meadow, with abundant Ranunculus acris and } \\
\text { Lychnis flos-cuculi }\end{array}$ & 1030 & 154 \\
\hline 2 & Południowo-Mazowieckie Hills & $\begin{array}{l}51^{\circ} 35^{\prime} 21^{\prime \prime} \mathrm{N} \\
20^{\circ} 18^{\prime} 57^{\prime \prime} \mathrm{E}\end{array}$ & 160 & Mown wet meadow, with abundant Ranunculus acris & 360 & 172 \\
\hline 3 & Południowo-Mazowieckie Hills & $\begin{array}{l}51^{\circ} 35^{\prime} 11^{\prime \prime} \mathrm{N} \\
20^{\circ} 17^{\prime} 37^{\prime \prime} \mathrm{E}\end{array}$ & 160 & Mown wet meadow, with abundant Ranunculus repens & 490 & 247 \\
\hline 4 & Silesian Lowland & $\begin{array}{l}51^{\circ} 18^{\prime} 35^{\prime \prime} \mathrm{N} \\
16^{\circ} 29^{\prime} 54^{\prime \prime} \mathrm{E}\end{array}$ & 130 & Mown wet meadow, with abundant Caltha palustris & 225 & 122 \\
\hline 6 & Ślęża Massif & $\begin{array}{l}50^{\circ} 50^{\circ} 46^{\prime} ’ \mathrm{~N} \\
16^{\circ} 43^{\prime} 56^{\prime} \mathrm{E}\end{array}$ & 290 & $\begin{array}{l}\text { Unmown wet meadow, dominated by Alopecurus pratensis } \\
\text { and Festuca pratensis }\end{array}$ & 550 & 63 \\
\hline 7 & Ślęża Massif & $\begin{array}{l}50^{\circ} 50^{\prime} 42^{\prime \prime} \mathrm{N} \\
16^{\circ} 44^{\prime} 11^{\prime \prime} \mathrm{E}\end{array}$ & 320 & Unmown wet meadow, with abundant Polygonum bistorta & 660 & 78 \\
\hline 8 & Wałbrzyskie Mountains & $\begin{array}{l}50^{\circ} 43^{\prime} 11^{\prime \prime} \mathrm{N} \\
16^{\circ} 18^{\prime} 39^{\prime \prime} \mathrm{E}\end{array}$ & 620 & Unmown wet meadow, with abundant Serratula tinctoria & 450 & 87 \\
\hline 9 & Stołowe Mountains & $\begin{array}{l}50^{\circ} 26^{\prime} 55^{\prime \prime} \mathrm{N} \\
16^{\circ} 19^{\prime} 18^{\prime \prime} \mathrm{E}\end{array}$ & 660 & Mown wet meadow, with abundant Ranunculus acris & 33,800 & 806 \\
\hline 10 & Stołowe Mountains & $\begin{array}{l}50^{\circ} 27^{\prime} 21^{\prime \prime} \mathrm{N} \\
16^{\circ} 19^{\prime} 16^{\prime \prime} \mathrm{E}\end{array}$ & 670 & Mown wet meadow, with abundant Ranunculus acris & 6,450 & 148 \\
\hline
\end{tabular}

*Population size: total number of flowering individuals counted in June 2007 
TABLE 2. $\mathrm{pH}$ and macroelement contents $\left(\mathrm{mg} \mathrm{kg}^{-1}\right)$ in the soil sampled from the 10 sites of Dactylorhiza majalis. Site numbers correspond to those in Table 1.

\begin{tabular}{|c|c|c|c|c|c|c|c|}
\hline Site & $\mathrm{pH}$ & $\mathrm{N}$ & $\mathrm{P}$ & $\mathrm{K}$ & $\mathrm{Ca}$ & $\mathrm{Mg}$ & S \\
\hline 1 & 5.2 & 3220 & 64 & 66 & 2610 & 241 & 926 \\
\hline 2 & 4.9 & 2273 & 43 & 47 & 1927 & 98 & 759 \\
\hline 3 & 4.8 & 2506 & 73 & 54 & 2630 & 199 & 899 \\
\hline 4 & 4.8 & 2393 & 47 & 37 & 2713 & 258 & 442 \\
\hline 5 & 5.8 & 8313 & 23 & 77 & 7239 & 1069 & 1607 \\
\hline 6 & 5.6 & 6225 & 37 & 92 & 1516 & 2618 & 472 \\
\hline 8 & 5.1 & 5903 & 33 & 218 & 3635 & 1011 & 496 \\
\hline 9 & 5.1 & 3355 & 19 & 95 & 3053 & 352 & 486 \\
\hline 10 & 5.1 & 3479 & 16 & 74 & 3316 & 182 & 418 \\
\hline
\end{tabular}

produces about 30 nectarless flowers. Fruits are set from June to July. As other species in the genus Dactylorhiza, D. majalis possesses little capacity for vegetative spread (Dijk et al. 1997). Propagation occurs mostly by seeds. Seed dispersal is restricted to the close vicinity of the mother plant. There is no indication of a seed or protocorm bank in $D$. majalis.

Individuals of $D$. majalis from ten sites (1-10) were examined, during full flowering, in June 2007. These sites represent a diverse assemblage of wet meadow communities in central (sites 1-3) and southwestern (sites 4-10) Poland. Sites 1-5 were located at low altitudes, in the Central Polish Lowland (130-160 $\mathrm{m}$ above sea level), and sites 6-10 at high altitudes, in the Sudety Foothills (sites 6, 7; 290, $320 \mathrm{~m}$ above sea level, respectively), and in the Sudety Mountains (sites 8-10; 620-670 m above sea level, respectively). The geology was heterogeneous with serpentinite (sites 6, 7), sandstone (sites 9, 10) bedrocks and mixed sediments (sites 1-5 and 8). The sites were distributed among forest and grasslands and differed in management regime. Six of them were mown every year (sites 1-4 early mown, in July, and sites 9, 10 late mown, in August), and four sites (5-8) were unmown. None of the sites was artificially fertilized. We obtained the information regarding the management regime of each site through personal observation and interviews with site managers. All studied populations contained more than 50 flowering individuals. The main characteristics of the sites and populations are listed in Table 1.

\section{Data collection}

\section{Measures of fitness components}

Ten (sites 1-5) and fifteen (sites 6-10) $1 \times 1$ plots were randomly chosen within each population with the aim of having at least 50 plants per site. In each plot, we counted the number of reproductive plants (individuals with flowers) and vegetative plants (non flowering). Length and width of each leaf (in $\mathrm{cm}$ ) of each of these individuals were measured and total leaf area of the plant was estimated. Total leaf area (plant size hereafter) was calculated by summing up the product $0.5 \times$ (leaf length) $\times$ (leaf width) for all leaves of a plant (Kindlmann and Balounová 1999; Janečkova et al. 2006). For all reproductive plants in each of the study plots, we also counted the number of flowers per plant. Afterwards three plant classes were distinguished: (a) juvenile plants; vegetative plants smaller than the smallest reproductive plant, (b) vegetative plants equal or larger than the smallest reproductive plant, and (c) reproductive plants with flowers as in Mendez and Karlsson (2004). A total of 536 reproductive plants and 245 vegetative plants were studied.

\section{Soil samples}

For all locations, where fitness components were determined in D. majalis, ten or fifteen soil samples $(15 \mathrm{~cm}-$ deep cores) were taken in the neighbourhood of the sampled plants. The samples were air-dried, thoroughly mixed and sieved $(2 \mathrm{~mm})$. Plant-available nutrients i.e., $\mathrm{P}$ and $\mathrm{K}$, $\mathrm{Ca}, \mathrm{Mg}$ were extracted using a $0.03 \mathrm{M}$ acetic acid solution and $1 \mathrm{M}$ ammonium acetate solution, respectively. Phosphorus was colorimetrically measured with vanadium molybdate, and $\mathrm{K}, \mathrm{Ca}$ and $\mathrm{Mg}$ levels were measured by flame atomic absorption spectrophotometery (FAAS; GBC Avanta PM). Soil total N content was measured using the Kjeldahl's method in an Autoanalyzer (Vapodest 40 Distillation Unit, Gerhardt), and total S content was measured by LECO-144 SC Analyzer. All the analyses were done in duplicate. All results for soils were calculated on a dry weight basis. The $\mathrm{pH}$ was measured using a $\mathrm{pH}$ meter (CP$-104)$ in $1 \mathrm{M} \mathrm{KCl}$ extract of the soil: $\mathrm{KCl}$ ratio of 1:2.5.

\section{Data analysis}

The sites were characterized according to their environmental variables by means of a principal component analysis (PCA). Variables considered were: altitude, soil N, P, K, $\mathrm{Ca}, \mathrm{Mg}, \mathrm{S}$ and $\mathrm{pH}$ (Table 1 and 2). The environmental variables having a loading greater than 0.6 in a factor were considered as related to that factor. The results of the PCA analysis were visualized by means of diagrams obtained by overlapping scores and loadings plots for PC1 vs PC2 (Legendre and Legendre 1998).

To describe the relationship between plant size and the flowering probability and to test for differences between the sites, we used the logistic equation (Wesselingh et al. 1993, 1997; Méndez and Karlsson 2004)

$$
p_{f}=1 /\left(1+e^{\mu+\alpha x}\right)
$$

where $\mathrm{x}$ is plant size (estimated total leaf area in $\mathrm{cm}^{2}$ ), and $\mathrm{p}_{\mathrm{f}}$ is the flowering probability.

Parameters $\mu$ and $\alpha$ of the fitted logistic curve determine the intercept with the $\mathrm{X}$-axis and the slope of the curve, respectively, and can be related to the threshold size for reproduction and percentage reproductives (Wesselingh et al. 1993). Both parameters are estimated by maximization of the likelihood function $L(\mu, \alpha)$, yielding an $L_{\max }$. The 
TABLE 3. Range of plant size (total leaf area in $\mathrm{cm}^{2}$ ) of Dactylorhiza majalis from 10 sites. $\mu$ and $\alpha$ are the parameters of the logistic regression relating flowering status to plant size; SRI: size of the smallest reproductive individual; ATS: average threshold size; RAN: transition range (size difference between the largest vegetative and the smallest reproductive individuals); \%R: percentage of reproductives. Sample size (n) for each site is given in the last column.

\begin{tabular}{|c|c|c|c|c|c|c|c|c|}
\hline Site & Plant size range & $\mu \pm \mathrm{SE}$ & $\alpha \pm \mathrm{SE}$ & SRI & ATS & RAN & $\% \mathrm{R}$ & $\mathrm{n}$ \\
\hline 1 & $1.6-105$ & $-1.859 \pm 0.438$ & $0.061 \pm 0.015$ & 10.1 & 30.2 & 52 & 49 & 89 \\
\hline 2 & $2.1-93$ & $-1.655 \pm 0.424$ & $0.053 \pm 0.013$ & 15.1 & 31.1 & 49 & 55 & 103 \\
\hline 3 & $1.9-118$ & $-1.390 \pm 0.391$ & $0.039 \pm 0.009$ & 14.8 & 35.0 & 62 & 58 & 87 \\
\hline 4 & $3.1-123$ & $-1.415 \pm 0.521$ & $0.083 \pm 0.018$ & 9.7 & 16.9 & 51 & 79 & 99 \\
\hline 5 & $4.1-148$ & $-2.632 \pm 1.112$ & $0.134 \pm 0.042$ & 19.2 & 19.7 & 28 & 89 & 86 \\
\hline 6 & $5.2-39$ & $-9.671 \pm 4.201$ & $0.595 \pm 0.236$ & 16.0 & 16.3 & 4.2 & 95 & 57 \\
\hline 8 & $6.1-72$ & $-14.072 \pm 5.466$ & $0.485 \pm 0.190$ & 24.5 & 29.1 & 5.8 & 87 & 65 \\
\hline 9 & $4.9-44$ & $-2.159 \pm 0.791$ & $0.135 \pm 0.038$ & 12.5 & 15.9 & 25 & 80 & 78 \\
\hline 10 & $4.1-54$ & $-2.776 \pm 1.014$ & $0.169 \pm 0.047$ & 15.7 & 16.4 & 22 & 93 & 55 \\
\hline
\end{tabular}

method is described in detail by Wesselingh et al. (1993, 1997). According to Méndez and Karlsson (2004), in addition to $\mu$ and $\alpha$, the following variables which can be related to flowering probability were calculated: the size of the smallest reproductive individual (SRI); the average threshold size (ATS), i.e. the size at which a plant has a $50 \%$ probability of flowering, obtained as ATS $=-\mu / \alpha$ the transition range (RAN), i.e. the difference between the biggest vegetative and the smallest reproductive individuals; and the percentage of reproductives $(\% \mathrm{R})$, calculated as the percentage of individuals equal or larger than SRI which were reproductive. Differences between sites in \% $\mathrm{R}$ were tested by means of a G-test (Zar 1999).

Simple linear regression was used to examine the relationship between plant size and flower production and differences in regression lines among populations were compared by ANCOVA (Zar 1999).

The PCA analysis was also executed with plant variables representing size-dependent fitness components (Table 3): $\mu, \alpha$ and SRI, ATS, RAN and $\%$ R and slope (b) and intercept (a) of the regression between plant size and flower production. Plant variables having a loading greater than 0.6 in a factor were considered as related to that factor. The results of the PCA analysis were visualized by means of diagrams obtained by overlapping scores and loadings plots for PC1 vs PC2 and PC1 vs PC3.

To investigate whether there was a relationship between environmental variables and size-dependent fitness components, sample scores for principal components were used as environmental variables for further multiple, stepwise regression analysis (with forward stepwise procedure). Parameters $\mu, \alpha, b$, a and ATS, SRI, RAN and $\%$ R were used as dependent variables. PCA axes representing environmental variables (altitude and soil macro-elements) were used as independent variables (Sokal and Rohlf 2003). All calculations were done using the CSS Statistica 8.0 program (StatSoft, Inc. 2008).

\section{RESULTS}

\section{Environment}

In the PCA of environmental variables (Tables 1 and 2, Fig. 1), the two main extracted factors together explained $71 \%$ of the observed variation in the variables. The first factor, accounting for $41 \%$ of variation, was mainly related

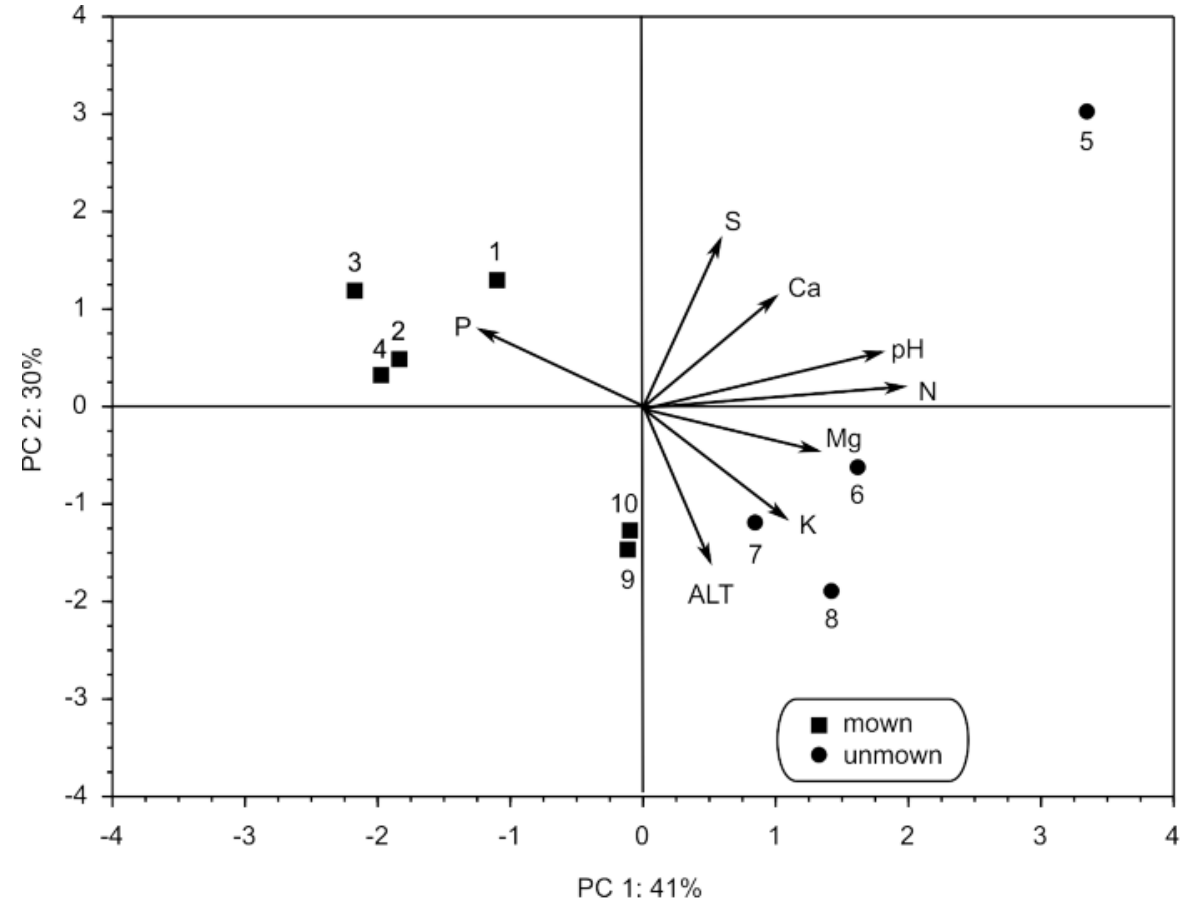

Fig. 1. Ordination of the 10 sites (squares and dots) along two axes extracted by a PCA analysis based on eight environmental variables measured at each site (Tables 1 and 2). Sites 1-5 are at low altitudes and 6-10 are at high altitudes. 


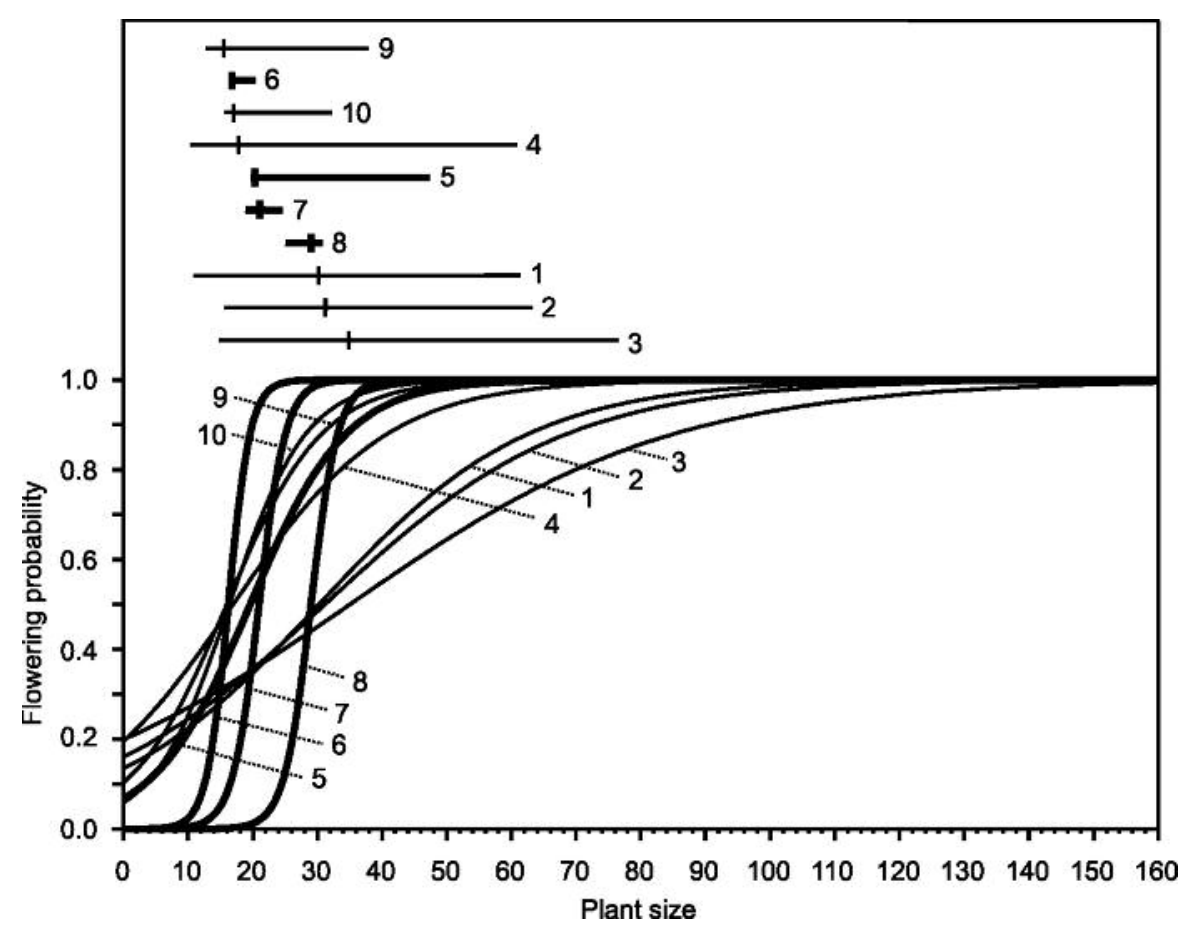

Fig. 2. Relationship between plant size (total leaf area in $\mathrm{cm}^{2}$ ) and flowering probability for each of the 10 sites (bold lines indicate the unmown sites). Segments above the curves indicate the transition range (RAN) and the average threshold size (ATS) for each sites (Table 3). to soil $\mathrm{N}$ and $\mathrm{Mg}$ concentrations and soil $\mathrm{pH}$ in the positive side and soil $\mathrm{P}$ concentration in the negative side. Soil $\mathrm{Ca}$ and $\mathrm{K}$ concentrations had similar loadings $(\approx 0.5)$ on the positive side of the first factor. The second factor, accounting for $30 \%$ of variation, was mainly related to soil S concentration in the positive side and altitude in the negative side. Soil $\mathrm{Ca}$ and $\mathrm{K}$ concentrations had similar loadings $(\approx 0.6)$ on the positive and negative side of the second factor (respectively). These factors can be interpreted as gradients in soil richness and altitude. Overall, two groups of sites could be distinguished (Fig. 1): (a) low altitude sites (1-4) had negative values for the first factor and positive values for the second factor (acid soils, moderately rich in $\mathrm{P}$ and $\mathrm{S}$, poor in $\mathrm{N}$ and $\mathrm{Mg}$ ), (b) high altitude sites (6-10) with positive and negative (near to zero) values for the first factor and negative values for the second factor (acid to slightly acid soils, poor in $\mathrm{P}$ and $\mathrm{S}$, moderately rich in $\mathrm{N}$ and moderately rich to rich in $\mathrm{Mg}$ ). The remaining low altitude site (5) is isolated from other sites. This site had positive values for both factors. The soil at this site is slightly acid, relatively rich in N, S and poor in P. Furthermore, the mown sites (1-4 and 9,10) and the unmown sites (5-8) were differentiated in the value of factor 1 , which was mainly related to $\mathrm{N}, \mathrm{P}, \mathrm{Mg}$ and $\mathrm{pH}$ (Fig. 1).

\section{Size-dependent fitness components}

Logistic regression indicating plant size is a robust predictor of flowering. Flowering probability significantly increased with plant size at all sites (all $P<0.0001$; Table 3 ). The fitted curves, based on the maximum likelihood analysis of the data of each site are presented in figure 2 . All curves differ significantly from each other, when log likelihoods are compared $\left(\chi_{9}^{2}=35.45 ; P<0.0001\right)$. Only three sites (6-8, unmown), at high altitudes, showed a steeply increasing flowering probability with plant size. At others such as 1-4 (mown), at low altitudes, the fraction flowering increased more gradually with plant size, and large, vegetative plants were found at these sites (Fig. 2).
This difference between these sites in the fitted curves is caused by smaller (more negative) $\mu$ and larger $\alpha$ for the sites 6-8 (Table 3 ). In agreement with the above-mentioned results, the transition ranges (RAN) for the sites 6-8 were quite narrow, indicating a sharp boundary between vegetative and reproductive plants with narrow overlap in size between each stage. The transition ranges for the sites 1-4 were wide, indicating a more gradual transition from vegetative to reproductive status and a large overlap in plant size of flowering and vegetative individuals (Table 3, Fig. 2). Overall, the plants growing at low altitudes (sites 1-5) had much higher threshold sizes for flowering than those at the high altitudes (sites 6-10), indicating the presence of a large variation in threshold sizes at the low altitudes. The plants at mown sites (1-4 and 9,10) had higher threshold sizes than those at unmown sites (6-8 except site 5).

Furthermore, different populations had quite different average threshold sizes (ATS) and the smallest reproductive individual (SRI) values (Table 3, Fig. 2). Smallest reproductive individuals were found at two sites (1 and 4, mown), at low altitudes. Three sites (1-3, mown), at low altitudes, showed the highest ATS values (Table 3, Fig. 2).

Percentage of reproductives $(\% \mathrm{R})$ ranged from 49 to 95\% (Table 3). All sites (except sites 1-3, mown, low altitude) clustered around percentage of reproductives between $79-95 \%$. There were significant differences between sites in percentage of reproductives $\left(\mathrm{G}_{9}=34.38 ; P\right.$ $<0.0001)$.

Linear regressions indicating plant size is also a robust predictor of flower production. Flower production significantly increased with plant size at all sites (most $P<0.001$, Table 4). Percentage of variance explained by the regression ranged from 19 to $51 \%$.

ANCOVA showed significant differences in slope $\left(\mathrm{F}_{9,516}\right.$ $=26.49 ; P=0.013)$ and intercept $\left(\mathrm{F}_{9,516}=154.41 ; \stackrel{P}{<}<\right.$ $0.001)$ values among sites. One unmown site (5), at low altitude, exhibited significantly higher intercepts than other sites. Other sites, such as 6 and 9 (unmown and mown, res- 
TABLE 4. Mean flower production and plant size (total leaf area of flowering individuals in $\mathrm{cm}^{2}$ ) of Dactylorhiza majalis from 10 sites. Slope (b) and intercept (a) values, percentage of variance explained $\left(\mathrm{R}^{2}\right)$ and significance $(P)$ are given for the regression analyses relating number of flowers to plant size. Sample size (n) for each site is indicated in the last column.

\begin{tabular}{|c|c|c|c|c|c|c|c|}
\hline Site & $\begin{array}{c}\text { Number } \\
\text { of flowers } \pm \mathrm{SD}\end{array}$ & $\begin{array}{c}\text { Plant size } \\
\text { in } \mathrm{cm}^{2} \pm \mathrm{SD}\end{array}$ & $\mathrm{b} \pm \mathrm{SE}$ & $\mathrm{a} \pm \mathrm{SE}$ & $\mathrm{R}^{2}$ & $P$ & $\mathrm{n}$ \\
\hline 1 & $17.7 \pm 6.6$ & $35.1 \pm 19.2$ & $0.246 \pm 0.029$ & $9.056 \pm 2.741$ & 0.51 & $<0.001$ & 42 \\
\hline 2 & $16.4 \pm 5.4$ & $37.2 \pm 16.8$ & $0.159 \pm 0.031$ & $10.466 \pm 2.789$ & 0.24 & $<0.001$ & 53 \\
\hline 3 & $14.9 \pm 5.1$ & $45.3 \pm 17.3$ & $0.192 \pm 0.024$ & $6.009 \pm 2.737$ & 0.42 & $<0.001$ & 47 \\
\hline 4 & $15.4 \pm 6.5$ & $45.1 \pm 24.4$ & $0.123 \pm 0.018$ & $9.866 \pm 2.637$ & 0.21 & $<0.001$ & 75 \\
\hline 5 & $16.7 \pm 5.6$ & $56.9 \pm 29.9$ & $0.081 \pm 0.017$ & $12.095 \pm 2.713$ & 0.19 & $<0.001$ & 74 \\
\hline 7 & $14.7 \pm 2.4$ & $31.8 \pm 7.1$ & $0.167 \pm 0.102$ & $9.377 \pm 4.147$ & 0.23 & $<0.01$ & 51 \\
\hline 8 & $15.8 \pm 2.7$ & $36.8 \pm 10.7$ & $0.109 \pm 0.061$ & $10.700 \pm 3.849$ & 0.19 & $<0.01$ & 46 \\
\hline 9 & $13.4 \pm 4.8$ & $26.7 \pm 10.2$ & $0.318 \pm 0.076$ & $4.855 \pm 3.291$ & 0.46 & $<0.001$ & 60 \\
\hline 10 & $14.7 \pm 3.9$ & $28.1 \pm 8.6$ & $0.193 \pm 0.085$ & $9.312 \pm 2.478$ & 0.18 & $<0.01$ & 41 \\
\hline
\end{tabular}

pectively), at high altitudes, showed the highest slopes (Table 4). This observation suggests that flower production at some sites at high altitude increased more steeply with plant size than at other sites.

\section{Relationships between size-dependent fitness components}

In the PCA of plant variables representing size-dependent fitness components (Tables 3 and 4), the three main extracted factors together explained $94 \%$ of the observed variation in the variables. The first factor, accounting for $51 \%$ of variation, was mainly related to variables representing flowering probability (SRI, $\alpha$ and $\% \mathrm{R}$ in the positive side and RAN and $\mu$ in the negative side; Fig. 3). Second factor, accounting for $28 \%$ of variation, was mainly related to the parameters of the equations describing sizedependent flower production ( $\mathrm{a}$ in the positive side and $\mathrm{b}$ in the negative side). Third factor, accounting for $15 \%$ of variation, was mainly related to ATS in the negative side (Fig. 3).

Among the variables representing size-dependent fitness components, the percentage reproductives $(\% \mathrm{R})$ was strongly, positively related to $\alpha$ and weakly, negatively related to $\mu$ (Fig. 3). \%R was also strongly, negatively related to RAN and ATS. However, RAN was not correlated with ATS. This indicates that sites in which RAN, ATS and $\mu$ decreased with percentage reproductives $(\% \mathrm{R})$ were also those in which flowering probability increased in a steeper way with plant size. This is consistent with the positive relationship between RAN and $\mu$ and the negative relationship between RAN and $\alpha$ as well as the negative relationship between parameters $\mu$ and $\alpha$ (Fig. 3). The negative relationship between parameters $\mu$ and $\alpha$ indicates that the sites in which flowering probability increased at smaller size were also those in which flowering probability increased in a more steep way with increasing size. Further, SRI was positively related to $\alpha$ and negatively related to RAN and $\mu$. Thus, there was a trend in the data-set for sites exhibiting higher SRI and $\alpha$ and lower RAN and $\mu$. Parameters $b$ and a were negatively correlated to each other, but not to variables related to flowering probability (Fig. 3). Results from figure 3 also agree with the correlation table between plant variables related to size-dependent components across sites (Table 5).

In the space defined by the three factors extracted by PCA, sites were arranged in a way consistent with the above-mentioned results (Tables 3 and 4, Fig. 2). The unmown sites (6-8), at high altitudes, showed narrow RAN, high $\alpha$ and \%R; while others, such as mown sites (1-4), at low altitudes, showed wide transition ranges (RAN). Sites 1 and 4 also showed the lowest SRI values and site 3 the highest ATS. Intercept (a) was the highest at unmown site (5), at low altitude, while the unmown site (6) and the mown site (9), at high altitudes, showed the highest slopes (b).

\section{Size-dependent fitness components and environment}

Significant $(P<0.05)$ multiple stepwise regression models was found for all the response plant variables except for the ATS, b and a $\left(\mathrm{R}^{2}=0.14, P=0.581 ; \mathrm{R}^{2}=0.14, P=\right.$ 0.594 and $\mathrm{R}^{2}=0.19, P=0.219$, respectively). Explanatory variables representing environmental gradients, i.e. soil richness and altitude (PC axes) showed a significant effect after forward selection for RAN, $\%$ R, SRI, $\mu$ and $\alpha$ (Table $6)$. The standard partial regression coefficient $(\beta)$ indicated that RAN and $\mu$ correlated negatively with PC1 (increasing $\mathrm{N}, \mathrm{Mg}$ and $\mathrm{pH}$, and decreasing $\mathrm{P}$ ), and positively with $\mathrm{PC} 2$ (increasing $\mathrm{S}$ and decreasing altitude). The relationship was significantly positive $(P<0.05)$ between $\mathrm{PC} 1$ and $\alpha$, $\% \mathrm{R}$ and SRI, and negative between PC2 and $\alpha$.

TABLE 5. Correlation matrix of simple linear coefficient values (Pearson r) for each pair of size-dependent fitness components analyzed in Dactylorhiza majalis from 10 sites; $r$ value in bold indicates component significantly $(P<0.05)$ correlated with a given component.

\begin{tabular}{cccccc}
\hline & $\mathrm{b}$ & $\mathrm{a}$ & $\mu$ & $\alpha$ & RAN \\
\hline $\mathrm{a}$ & $\mathbf{- 0 . 8 7 3}$ & & & & \\
$\mu$ & 0.118 & -0.013 & & & \\
$\alpha$ & 0.073 & -0.185 & $\mathbf{- 0 . 9 3 3}$ & $\mathbf{0 . 8 9 1}$ & \\
RAN & -0.059 & 0.064 & $\mathbf{0 . 8 2 4}$ & $\mathbf{- 0 . 2 9 2}$ & 0.520 \\
ATS & -0.207 & 0.182 & 0.052 & 0.609 & $\mathbf{- 0 . 6 5 7}$ \\
SRI & -0.476 & -0.342 & $\mathbf{- 0 . 7 5 7}$ & $\mathbf{0 . 6 6 1}$ & $\mathbf{- 0 . 8 3 1}$ \\
\%R & -0.102 & -0.024 & -0.530 & $\mathbf{- 0 . 7 9 0}$ \\
\hline
\end{tabular}



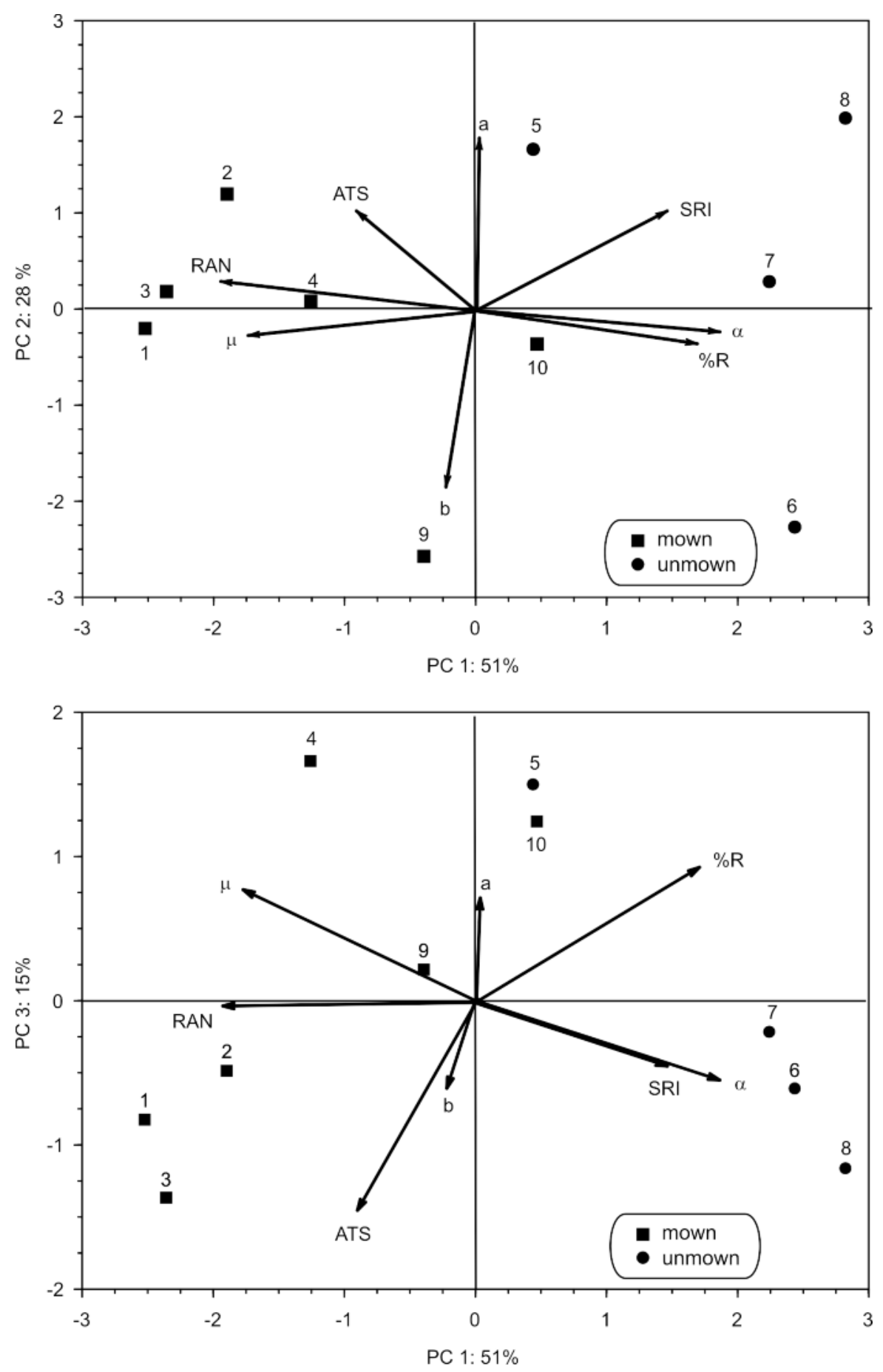

Fig. 3. Ordination of the 10 sites (squares and dots) along three axes extracted by a PCA analysis based on eight variables related to size-dependent fitness components, measured at each site (Tables 3 and 4). Sites $1-5$ are at low altitudes and 6-10 are at high altitudes.

\section{DISCUSSION}

Wide ranges of soil nutrient concentrations were observed for all elements across the study sites. In this study, only concentrations of soil $\mathrm{N}$ at all unmown sites both at low altitude and high altitude and $\mathrm{Mg}$ at two sites, on serpentine-derived soils, exceeded the normal levels reported for mineral soils in Poland. However, maximum concentrations of the $\mathrm{N}$ detected in the soils in this study do not approach those documented for the organic soils found in Poland (Mazur 1991), but rather seem to be representative of levels encountered in unmown meadow areas. These soil Mg concentrations at serpentine sites are in agreement with those presented by Kruckeberg (2004), confirming that the ser- pentine soils typically contain higher levels of $\mathrm{Mg}$. According to Dijk et al. (1997), Dijk and Grootjans (1998) the availability of $\mathrm{N}$ and $\mathrm{P}$ plays a critical role in orchid growth and survival. In our study, at all the sites, soil P levels were absolutely low, but at the mown sites, at low altitudes, were relatively higher than those at the other sites.

Flowering in Dactylorhiza majalis appears to be strongly size dependent. The probability of flowering significantly increased with the size of the plant in all populations, indicating that individuals do not flower until they reach a threshold size. This is in agreement with Wells et al. (1998), Willems and Dorland (2000) and Kull (2002), who state that in some terrestrial orchids, flowering is dependent on a threshold plant size. 
TABLE 6. Multiple stepwise regression analysis (forward selection) of environmental variables (two PC axes) on size-dependent fitness components of Dactylorhiza majalis. Only the significant models and the significant predictor variables, after forward selection are shown. Directions of associations (+ or - ) between the variables and the two PCs are presented. $\beta=$ standardized partial regression coefficient; $\mathrm{t}=\mathrm{t}$-statistic; $P=$ probability level; $\mathrm{df}=\mathrm{degrees}$ of freedom; $\mathrm{MS}=$ mean square; $\mathrm{F}=\mathrm{F}$-statistic; $\mathrm{R}^{2}=$ square multiple regression coefficient.

\begin{tabular}{|c|c|c|c|c|c|c|c|}
\hline \multirow{2}{*}{ Variable } & \multirow{2}{*}{$\beta$} & \multirow{2}{*}{$\mathrm{t}$} & \multirow{2}{*}{$P$} & \multicolumn{4}{|c|}{ ANOVA } \\
\hline & & & & $\mathrm{df}$ & MS & $\mathrm{F}$ & $P$ \\
\hline \multicolumn{8}{|l|}{ RAN $\left(\mathrm{R}^{2}=0.93\right)$} \\
\hline $\begin{array}{l}\text { PC } 1 \\
{[(+\mathrm{N}),(-\mathrm{P}),(+\mathrm{Mg}),(+\mathrm{pH})]}\end{array}$ & -0.77 & -10.47 & 0.000016 & Regression 2 & 2021.43 & 89.03 & 0.000011 \\
\hline $\begin{array}{l}\text { PC } 2 \\
{[(+\mathrm{S}),(- \text { alt })]}\end{array}$ & 0.61 & 8.27 & 0.000074 & Residual 7 & 22.71 & & \\
\hline \multicolumn{8}{|l|}{ Parameter $\mu\left(\mathrm{R}^{2}=0.64\right)$} \\
\hline $\begin{array}{l}\text { PC } 1 \\
{[(+\mathrm{N}),(-\mathrm{P}),(+\mathrm{Mg}),(+\mathrm{pH})]}\end{array}$ & -0.55 & -2.41 & 0.0364 & Regression 2 & 63.13 & 6.23 & 0.0278 \\
\hline $\begin{array}{l}\text { PC } 2 \\
{[(+\mathrm{S}),(- \text { alt })]}\end{array}$ & 0.58 & 2.57 & 0.047 & Residual 7 & 10.11 & & \\
\hline \multicolumn{8}{|l|}{ Parameter $\alpha\left(\mathrm{R}^{2}=0.68\right)$} \\
\hline $\begin{array}{l}\text { PC } 1 \\
{[(+\mathrm{N}),(-\mathrm{P}),(+\mathrm{Mg}),(+\mathrm{pH})]}\end{array}$ & 0.60 & 2.81 & 0.0258 & Regression 2 & 0.1385 & 7.59 & 0.0176 \\
\hline $\begin{array}{l}\text { PC } 2 \\
{[(+\mathrm{S}),(- \text { alt })]}\end{array}$ & -0.57 & -2.69 & 0.0310 & Residual 7 & 0.0182 & & \\
\hline \multicolumn{8}{|l|}{$\% R\left(R^{2}=0.70\right)$} \\
\hline $\begin{array}{l}\text { PC } 1 \\
{[(+\mathrm{N}),(-\mathrm{P}),(+\mathrm{Mg}),(+\mathrm{pH})]}\end{array}$ & 0.72 & 3.47 & 0.0105 & $\begin{array}{l}\text { Regression } 2 \\
\text { Residual } 7\end{array}$ & $\begin{array}{l}893.09 \\
109.12\end{array}$ & 8.19 & 0.0147 \\
\hline $\begin{array}{l}\text { PC } 1 \\
{[(+\mathrm{N}),(-\mathrm{P}),(+\mathrm{Mg}),(+\mathrm{pH})]}\end{array}$ & 0.67 & 2.53 & 0.0351 & $\begin{array}{l}\text { Regression } 1 \\
\text { Residual } 8\end{array}$ & $\begin{array}{l}79.49 \\
12.41\end{array}$ & 6.41 & 0.0351 \\
\hline
\end{tabular}

Our results demonstrated that there were significant differences within and between the sites in threshold size for flowering in D. majalis. According to Wesselingh et al. (1997) and Mendez and Karlsson (2004), size-dependent flowering can be environmentally influenced. Plants growing at low altitudes had much higher threshold sizes and flowered at larger size than those growing at high altitudes. Within-population variation in threshold size was larger in mown sites than unmown sites. Furthermore, the plants growing in mown sites of low altitudes exhibited the largest variation in threshold size for flowering. Plants from unmown sites of high altitudes showed the smallest variation in threshold size and sharp increase in flowering probability with size. These results are in agreement with studies showing that the threshold size for flowering should decrease in adverse environments as adaptive response to environmental adversities (Berrigan and Koella 1994; Mendez and Karlsson 2004; Bonser and Aarssen 2009). Plants growing at higher altitudes are commonly smaller than their low-altitude counterparts. A small size at high altitudes is usually considered as an effect of the severe climate. In this environment, plants have tendency to initiate reproduction at a smaller size (Karlsson and Jacobson 2001). Moreover, the lowered threshold size for flowering at unmown sites may also be a result of the lack of mowing and enhanced competition with surrounding vegetation. According to Wotavová et al. (2004) and Janečková et al. (2006), mowing may influence the morphometric characteristics of $D$. majalis at the sites via its effect on the species composition. These authors also state that mowing of competing vegetation, every year, appears necessary to maintain the large flowering individuals of $D$. majalis.

Flower production in D. majalis appears to be strongly size dependent. Our results detected a significant, positive correlation between plant size and flower production at all sites. This is in agreement with Hrivnák et al. (2006), indicating that flowering $D$. majalis individuals, likely use some energy achieved from photosynthesis to the production of flowers in the same season. A significant positive relationship between plant size and flower production has been documented for other terrestrial orchids, for example, Cyclopogon cranichoides (Calvo 1990), Orchis simia (Willems and Ellers 1996) and Cypripedium acaule (Primack and Stacy 1998).

There was also significant difference between sites in size-dependent flower production. According to Willems and Ellers (1996), relationship between plant size and flower production in terrestrial orchids can be environmentally influenced. Our results showed that at some sites, at 
high altitudes, the fit flower production on plant size had slope clearly higher than at other sites. This indicates that individuals of $D$. majalis may change their allocation strategy, investing relatively more in flower production with increasing plant size. However, no pattern in size-dependent flower production was found relative to the environmental gradients (soil richness and altitude).

The results of stepwise regression analysis enabled identification of the environmental gradients that best explain the variance patterns of the flowering probability and the variables related to flowering probability. The range of threshold size and parameter $\mu$ of the logistic regression line describing size-dependent flowering probability decreased with increasing soil $\mathrm{N}$ and $\mathrm{Mg}$ concentrations and altitude and decreasing soil $\mathrm{P}$ and $\mathrm{S}$ concentrations. On the contrary, parameter $\alpha$ of the logistic regression line correlated positively with these environmental gradients. The percentage of reproductives in the populations tended to increase at the sites rich in $\mathrm{N}$ and $\mathrm{Mg}$, and poor in $\mathrm{P}$. Variation explained by these environmental gradients was high and ranged from $64 \%$ to $93 \%$. According to Bonser and Aarssen (2009), environmental conditions limiting growth or increasing mortality can favor the initiation of reproduction at relatively small sizes. Dijk and Olff (1994) demonstrated that the $\mathrm{N}$ and $\mathrm{P}$ fertilization decreased frequency, total biomass and flowering of $D$. majalis in hay meadows, in contrast to the application of $\mathrm{K}$ suggesting that beside changes in competition equilibrium, direct toxicity of high nutrient levels might also play a role. In asymbiotic culture, however, the species showed optimal growth at low $\mathrm{N}$, but high $\mathrm{P}$ concentrations. Moreover, higher $\mathrm{N}$ concentrations were shown to affect growth of D. majalis seedlings negatively in asymbiotic culture (Dijk and Eck 1995). Our data suggest that plants at the high altitude sites, rich in $\mathrm{N}$ and $\mathrm{Mg}$ and poor in $\mathrm{P}$ and $\mathrm{S}$ were more likely to enter the reproductive phase than the plants with a similar size at other sites. Furthermore, the populations of D. majalis tended to increase reproductive probability (through the percentage of reproductives) in environments that are generally unfavourable to their persistence and growth (Dijk and Olff 1994).

Most of the size-dependent components of flowering probability were correlated with each other. No significant relationship was found between range of the threshold size and the average threshold size (i.e., the size at which the flowering probability is $50 \%$ ). Similar result was obtained for biennial Cynoglossum officinale (Wesselingh et al. 1993). An opposite result was reported for perennial Pinquicula vulgaris (Mendez and Karlsson 2004) where a positive relationship was observed between range of threshold size and the average threshold size. Mendez and Karlsson (2004), however, did not find significant relationships between parameters $\mu$ or $\alpha$ of logistic regression line describing flowering probability and the range of threshold size and the percentage of reproductives. Our results indicated that the stepper slope of logistic regression line describing flowering probability (parameter $\alpha$ ) was negatively related to the range of threshold size, suggesting a trade-off between the measured size-dependent fitness components. Further the parameter $\alpha$ was positively related to a larger percentage of reproductive individuals. No significant relationships were found between size-dependent flowering components and size-dependent flower production.
In conclusion, considerable between-site variation was found for size-dependent flowering components and sizedependent flower production in D. majalis. Variation in size-dependent flowering probability, the threshold size for reproduction and the percentage of reproductives was significantly related to altitude, soil nutrient level and site management (mowing). However, no pattern in size-dependent flower production was found relative to the measured environmental variables. Most of the size-dependent components of flowering probability were related to each other but not with the size-dependent flower production.

\section{LITERATURE CITED}

BEGON M., TOWNSEND C.R., HARPER J.L. 2008. Ecology: from individuals to ecosystems (4th Edition.) Blackwell Publishing, Oxford, $738 \mathrm{pp}$.

BERRIGAN D., KOELLA J.C. 1994. The evolution of reaction norms: simple models for age and size at maturity. J. Evol. Biol. 7: 549-566.

BONSER S.P., AARSSEN L.W. 2009. Interpreting reproductive allometry: Individual strategies of allocation explain sizedependent reproduction in plant populations. Perspect. Plant Ecol. Evol. Syst. 11:31-40.

BRZOSKO E. 2002. The dynamics of Listera ovata populations on mineral islands in the Biebrza National Park. Acta Soc. Bot. Pol. 71:243-251.

BRZOSKO E. 2003. The dynamics of island populations of Platanthera bifolia in the Biebrza National Park (NE Poland). Ann. Bot. Fennici 40: 243-253.

CALVO R.N. 1990. Four-year growth and reproduction of Cyclopogon cranichoides (Orchidaceae) in South Florida. Am. J. Bot. 77(6): 736-741.

DIJK E., ECK N.D. 1995. Axenic in-vitro nitrogen and phosphorus responses of some Dutch marsh orchids. New Phytol. 131: 353-359.

DIJK E., GROOTJANS A.B. 1998. Performance of four Dactylorhiza species over complex trophic gradient. Acta Bot. Neerl. 47(3): 351-368.

DIJK E., OLFF H. 1994. Effects of nitrogen, phosphorus and potassium fertilization on field performance of Dactylorhiza majalis. Acta Bot. Neerl. 43: 383-392.

DIJK E., WILLEMS J.H., VAN ANDEL J. 1997. Nutrient response as key factor to the ecology of orchid species. Acta Bot. Neerl. 46: 339-363.

EHLERS B.K., OLESEN J.M. 2004. Flower production in relation to individual plant age and leaf production among different patches of Corydalis intermedia. Plant Ecol. 174: 71-78.

GREGG K.B. 2004. Recovery of showy lady's slippers (Cypripedium reginae Walter) from moderate and severe herbivory by white-tailed deer (Odocoileus virginianus Zimmerman). Nat. Areas J. 24: 232-241.

HRIVNÁK R., GÖMÖRY D. CVACHOVÁ A. 2006. Inter-annul variability of the abundance and morphology of Dactylorhiza majalis (Orchidaceae-Orchideae) in two permanent plots of a mire in Slovakia. Phyton, 46: 27-44.

JANEČKOVÁ P., WOTAVOVÁ K., SCHÖDELBAUEROVÁ I., JERSÁKOVÁ J., KAGAYA M., TANI T., KACHI N. 2009. Variation in flowering size and age of facultative biennial, Aster kantoensis (Comositae), in response to nutrient availability. Am. J. Bot. 96: 1808-1813.

JANEČKOVÁ P., WOTAVOVÁ K., SCHÖDELBAUEROVÁ I., JERSÁKOVÁ J., KINDLMANN P. 2006. Relative effects of management and environmental conditions on performance and survival of populations of a terrestrial orchid, Dactylorhiza majalis. Biol. Conserv. 129: 40-49. 
KARLSSON P.S., JACOBSON A. 2001. Onset of reproduction in Rhododendron lapponicum shoots: the effect of shoot size, age, and nutrient status at two subarctic sites. Oikos 94: 279-286.

KĄCKI Z., DAJDOK Z., SZCZĘŚNIAK E. 2003. Czerwona lista roślin naczyniowych Dolnego Śląska. In: Z. Kącki (ed.), Zagrożone gatunki flory naczyniowej Dolnego Śląska. Instytut Biologii Roślin UWr, PTPP Pro Natura, Wrocław, pp: 9-65. (in Polish with English summary)

KINDLMANN P. 2006. Relative effects of management and environmental conditions on performance and survival of populations of terrestrial orchid, Dactylorhiza majalis. Biol. Conserv. 129: 40-49.

KINDLMANN P., BALOUNOVÁ Z. 1999. Flowering regimes of terrestrial orchids: unpredictability or regularity? J. Veg. Sci., 10: 269-273.

KRUCKEBERG A.R. 2004. Geology and plant life. The effects of landforms and rock types on plants. University of Washington Press, Seattle-London, $362 \mathrm{pp}$.

KULL T. 2002. Population dynamics of north temperate orchids. In: T. Kull, J. Arditti (eds), Orchid biology. Reviews and perspectives, VIII. Kluwer Academic Publishers, Dordrecht, pp. 139-165.

KUSS P., REES M., ÆGISDÓTTIR H.H., ELLNER S.P., STÖCKLING J. 2008. Evolutionary demography of long-lived monocarpic perennials: a time-lagged integral projection model. J. Ecol. 96: 821-832.

LEGENDRE P., LEGENDRE L. 1998. Numerical ecology. Elsevier Science B.V., Amsterdam, 853 pp.

LIENERT J. 2004. Habitat fragmentation effects on fitness of plant populations - review. J. Nat. Conserv. 12: 53-72.

MAZUR T. 1991. Azot w glebach uprawnych. PWN, Warszawa, 240 pp. (in Polish).

MÉNDEZ M., KARLSSON P.S. 2004. Between-population variation in size-dependent reproduction and reproductive allocation in Pinguicula vulgaris (Lentibulariaceae) and its environmental correlates. Oikos 104: 59-70.

METCALF J.C., ROSE K.E., REES M. 2003. Evolutionary demography of monocarpic perennials. Trends Ecol. Evol. 18: 471-480.

MIREK Z., ZARZYCKI K., WOJEWODA W., SZELĄG Z. 2003. Red list of plants and fungi in Poland. W. Szafer Institute of Botany, Polish Academy of Science, Kraków, 99 pp.

PINO J., SANS F.X., MASALLES R.M. 2002. Size-dependent reproductive pattern and short-term reproductive cost in Rumex obtusifolius L. Acta Oecol. 23: 321-328.
PRIMACK R., STACY E. 1998. Cost of reproduction in the pink lady' s slipper orchid (Cypripedium acaule, Orchidaceae): an eleven-year experimental study of three populations. Am. J. Bot. 85(12): 1672-1679.

REES M., CRAWLEY M.J. 1989. Growth, reproduction and population dynamics. Funct. Ecol. 3: 645-653.

ROCKWOOD L.L. 2006. Introduction to population ecology. Blackwell Publishing, 339 pp.

SOKAL R.R., ROHLF F.J. 2003. Biometry. The principles and practice of statistics in biological research. Freeman and Company, New York, 859 pp.

STATSOFT INC. 2008. Statistica (data analysis software system), version 8. StatSoft Inc., Tulsa, USA.

WEINER J., ROSENMEIER L., MASSONI E.S., VERA J.N., PLAZA E.H., SEBASTIÀ M.T. 2009. Is reproductive allocation in Senecio vulgaris plastic? Botany 87: 475-481.

WELLS T.C.E. ROTHERY P., COX R., BAMFORD S. 1998. Flowering dynamics of Orchis morio L. and Herminium monorchis (L.) R.Br. at two sites in eastern England. In: S. Waite (ed.), Orchid population biology: conservation and challenges. Bot. J. Linn. Soc. 126: 39-48.

WESSELINGH R.A., DE JONG T.J., KLINKHAMER P.G.L., VAN DIJK M.J., SCHLATMANN E.G.M. 1993. Geographical variation in threshold size for flowering in Cynoglossum officinale. Acta Bot. Neerl. 42(1): 81-91.

WESSELINGH R.A., KLINKHAMER P.G.L., DE JONG T.J., BOORMAN L.A. 1997. Threshold size for flowering in different habitats: effects of size-dependent growth and survival. Ecology, 78(7): 2118-2132.

WILLEMS J.H., DORLAND E. 2000. Flowering frequency and plant performance and their relation to age in the perennial orchid Spiranthes spiralis (Orchidaceae). Acta Bot. Neerl. 46: 365-375.

WILLEMS J.H. ELLERS J. 1996. Plant performance and population characteristics of Orchis simia (Orchidaceae) in two extremes of its distribution area. Flora, 191: 41-48.

WILLEMS J.H., MELSER C. 1998. Population dynamics and lifehistory of Coeloglossum viride (L.) Hartm.: an endangered orchid species in The Netherlands. Bot. J. Linn. Soc. 126: 83-93.

WOTAVOVÁ K., BALOUNOVÁ Z., KINDLMANN P. 2004. Factors affecting persistence of terrestrial orchids in wet meadows and implications for their conservation in changing agricultural landscape. Biol. Conserv. 118: 271-279.

ZAR J.H. 1999. Biostatistical analysis. Prentice Hall, Upper Saddle River, New Jersey, 663 pp. 